\section{Typy zieleni i elementy wodne w przestrzeni dawnego miasta-twierdzy Trebinje}

Types of greenery and water features in the space of the former fortress-city of Trebinje

\section{Streszczenie}

Artykuł poświęcony jest analizie systemu zieleni oraz wody w mieście, będącym na przełomie XIX i XX wieku nadgraniczna twierdza. W kameralnej skali miasta, błękitno-zielona infrastruktura stanowi istotny element kompozycji, oraz czytelne powiazanie przestrzeni publicznych. Jest to zarazem czytelny przykład wykorzystania specyficznej lokalizacji i dostępnych zasobów naturalnych przez organizm miejski

Abstract

The article focuses on an analysis of the system of greenery and water of a city that was a frontier fortress at the turn of the nineteenth and twentieth centuries. In the cameral scale of the city, the blue and green infrastructure constitutes an essentia compositional element and a link between public spaces. It is also a legible example of the use of a specific location and accessible natural resources by an urban organism.

Stowa kluczowe: woda w mieście, zieleń publiczna, zrównoważony rozwój
Keywords: water in the city, public greenery, sustainable development

Trebinje to najbardziej wysunięte na południe miasto Republiki Serbskiej w Bośni i Hercegowinie, stanowiące region ki Trebišnijcy, u podnóża góry Leotar, na granicy trzech

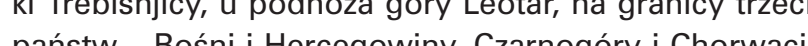
panstw-Bosn i Hodża Trebinje znajuje munkacynych - drog relaw Be 7 wad - Dubrownik oraz Mustar - Podgorca. Zal Dubrownika, $115 \mathrm{~km}$ od Mostaru, $120 \mathrm{~km}$ od Podgoricy, Čilipi (koło Dubrownika, w odległości 40 km).

1. Miasto

Rozwój urbanistyczny Trebinje został uksztattowany przez rożnorodne uwarunkowania i ich wzajemne zależności. Panujący klimat wynika z położenia geograficzne go na przelomie wysokich pasm górskich, w glębi lądu, lecz w pobliżu południowego wybrzeża Adriatyku. Specyficzna, nadgraniczna lokalizacja miasta, miała wpływ na jego historyczny rozwój pod względem gospodarczym, kulturowym, a także strategicznym - militarnym
Trebinje is the southernmost city of the Serbian Republic in Bosnia and Herzegovina, constituting a local centre of settlement. It lies in the valley of the border of River, at the foot of Mount Leotar, at the Montenegro and Croatia. Trebinje is located at the intersection of important circulation routes-roads connecting Belgrade with Dubrovnik and Mostar with Podgorica. The city is only $27 \mathrm{~km}$ away from Dubrovnik, $115 \mathrm{~km}$ away from Mostar, $120 \mathrm{~km}$ from Podgorica and $360 \mathrm{~km}$ away from Belgrade. The closest airport is in Čilipi in Croatia, (near Dubrovnik, a
a distance of $40 \mathrm{~km}$ away).

1. The city

The urban development of Trebinje has been shaped by varied conditions and their mutual interdependencies. The climate of the city is the result of its geographic placement at an intersection of tall mountain southern shore of the Adriatic Sea. The specific, frontier location of the city has influenced its historica development in economic, cultural and strategic and ranges, located deep inland, yet in the vicinity of the
Z kolei morfologia terenu i przepływająca rzeka Trebišnjistrzennej zabudowy. Scisłe centrum miasta powstało w dolinie i szerokiej strefie przybrzeżnej rzeki, zaś dominująca w typologii zabudowa mieszkalna jednorodzinna - u podnóża wzgórz i wzdłuż głównych szlaków komunikacyjnych - prowadzących do Mostaru i Dubrownika. Na zmianę struktury ludności, oraz na nowe kierunki ekspansji zabudowy miejskiej, istotny wpływ miały procesy demograficzne w okresie wojny 1992-1995. ${ }^{3}$. Gmina Trebinje zajmuje powierzchnię $904 \mathrm{~km}^{2}$. Według szacunków ${ }^{4}$ w latach 2002-2015 na tym obszarze mieszkało 30 627 mieszkańców, z czego mniej niż 10\% mieszkańców mieszka na terenach wiejskich.

Lokalni badacze ${ }^{5}$ wyróżniaja cztery fazy nowożytnego rozwoju miasta, z których każda nadaje specyficzny i odrebny wyraz morfologiczny. W obrębie murów Starego Miasta oraz na zboczach wzgórza Hrupjela (dzielnica Krš) powstała na poły organiczna, średniowieczna zabudowa z okresu panowania tureckiego. Znaczny ozwój tkanki miejskiej oraz infrastruktury (m.in. dworzec kolejowy, wodociąg miejski, budynki użyteczności publicznej, zespoły koszarowe itp.) nastąpit, gdy miasto znalazło się w strefie wpływów Austro-Weggier i pełniło funkcje twierdzy. Kolejne etapy to okres Krolestwa Jugosławii, oraz okres po drugiej wojnie światowej - ze szczególnym naciskiem na następstwa wojny domowe po 1995 roku.

Centrum miasta w największej mierze nosi cechy charakterystyczne dla okresu do drugiej wojny światowej, z wyrazistą sylwetą Starego Miasta nad lustrem rzeki, stanowiącą oryginalne nadbrzeże. Zasadnicza ekspansja terytorialna miasta i wzrost rozwoju istniejącej struktury miejskiej nastapił po II wojnie światowej. Intensywna zabudowa mieszkaniowa - wielorodzinna, wkroczyła na tereny na wschodnim brzegu Trebišnjicy. Najnowsze realizacje (powstate po 1995 roku), to nieliczne obiekty żyzaczności publicznej w pobliżu centrum miasta, kilk wielkopowierzchniowych obiektów handlowych, przede wsystkim zas - zywiowa zabudowa miszkaiowa jednorodzinna, na przedmieściach.

Wspótczing na predmiesciach. Wspolczesnie ceerte

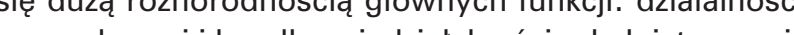
gospodarzeji ha jej, dzi i wosci szolnictwa wyzszego, mieszkalnej jedno-i wielorodzinnej, zaplecza instytucjonalnego, edukacji, służby zdrowia, kultury obiektów sportowych i rekreacyjnych, obiektów religijnych, parkow i terenow zielonych. Im dalej od centrum ym intensywność maleje, na rzecz monofunkcjonalne zabudowy mieszkaniowej. Osiedla bloków mieszkalnych wybudowanych po 1960 roku, w myśl obowiązujących wowczas normatywow urbanistycznych, wyposazone zostały w niezbędną infrastrukturę, placówki oświaty, oraz niewielkie obiekty handlowe - słuzące zapewnieniu podstawowych potrzeb mieszkanców. Oprócz braku obiektów usług towarzyszących, cechą stref peryferyjnych jest słaba infrastruktura miejska, brak regulaci military terms'. In turn, the morphology of the terrain and the nearby Trebisnjica River have affected the shape and development of the spatial structure of its development. The strict centre of the city emerged in the valley and the broad waterfront zone of the river, while single-family residential buildings that are dominant in its building typology ${ }^{2}$-at the foot of the nearby hils and along the main circulation trails-leading to Mostar and Dubrovnik. The change the popula cantly affected by demographic processes during the war between 1992 and $1995^{3}$. The community of Trebinje occupies an area of $904 \mathrm{~km}^{2}$. According to estimates 4 in the years 2002-2015 the area was inhabited by 30627 residents, of which less than $10 \%$ resided in rural areas.

Local scholars ${ }^{5}$ distinguish four phases of the modern development of the city, each of which gives a specific and separate morphological expression. Within the walls of the Old Town and on the slopes of Hrupelja Hill (the Krś district) a semi-organic and semi-Medieval form of development emerged, dated to the period of Turkish rule. A significant development of urban tissue and inf rastructure (e.g. the railway station, the municipal waterworks, public buildings, barracks complexes, etc.) took place when the city found itself in the Austro-Hungarian sphere of influence and fulfiled the function of a fortress. Subof Yugostaves as well as the one after the Second World With particur emphas on the consequences of the civil war after 1995

The centre of the city bears qualities distinct of the Theriod after the Second World War to the of the extent, with an expressive skyline of the Old Town above the mirror-like surface of the river, constituting an original waterfront. A fundamental territoria expansion of the city and an increase of the development of the extant urban structure took place after the Second World War. Dense multi-family residentia development encroached upon areas on the eastern shore of the Trebišnjica. The latest completed projects (built after 1995) include a small number of pubIic buildings near the city centre, a number of big box stores, but primarily - the lively spread of residentia buildings-single-family ones-in the suburbs At present, the central urban zone is characterised by a great degree of variety in terms of main functions: economic and retail activity, higher education, mult services, eduction, helthcase, culture, sports and recreation facilities, religious structures, parks and green areas. The further we move away from the centre, the lower the city's urban density becomes, in favour of monofunctional residential buildings. Housing estates composed of blocks of flats built after 1960 in line with then-enforced urban planning standards were supplied with the necessary infrastructure, educational facilities and small retail buildings-meant to satisfy the basic needs of residents. Besides a lack of accompanying service buildings, 
przestrzennej ulic i nielicznych przestrzeni publicznych. Często wystẹpuja rowniez grunty rolne na odosobnionych działkach wśród zabudowy o miejskim charakterze.

\section{Twierdza}

Bośnia i Hercegowina, zamieszkała przez ludność słowiańska, była w XIX wieku najbardziej na północ wy sunieta prowincja Imperium osmańskiego. W myś ustaleń kongresu berlí́skiego (1878), wprowadzajacego nowy podział cześci świ nowy podzlal częsci swiata po wojnie rosyjsko-tureckiej, binje, przy szlaku Dubrownik - Sarajewo, było jedynym ośrodkiem nadgranicznym, do którego doprowadzono linię kolejową ${ }^{6}$. $Z$ tego względu przewidywano jego funkcje jako istotnego punktu przeładunkowego dla celów wojskowych, oraz zaplecza logistycznego (oryg. niem. Depotpunkt). Miasto było też w dogodnym położeniu dla przeprowadzenia zgrupowania wojsk operujących $w$ kierunku Czarnogóry (ok. 14 km od ówczesnej granicy). Podstawowym zadaniem twierdzy Trebinje, w razie spodziewanego konfliktu, było zabezpieczenie $w$ stadium alarm mobilizacji jednostek $w$ sile brygady górskiej'

Aby swobodnie moźna było zrealizować wymienione wyżej zadania, potrzebny był przestronny obszar zamknięty umocnieniami tzw. rdzenia, czyli wewnętrznego obwodu fortyfikacji sasiadującego bezpośrednio z miastem. Dyzurna obsada rozlokowana była w budynkach koszarowych - warto zauważyć, iż zespół koszar obronnych Defensionslager zajmował na początku XX wieku blisko 1/3 zabudowanej powierzchni miasta. Od strony południowej dawna ulica Cesarska (oryg. Kaiserstraße) - obecnie główna ulica Kralja Petra Prvog Oslobodica, przechodzi bezpośrednio przy dawnym zespole koszarowym ${ }^{8}$. Wzdłuz tej ulicy zieleń z oryginalnym, zachowa nym starodrzewiem tworzy niewielki park ${ }^{9}$

Pierwotne założenie $z$ lat 80 . XIX wieku obejmowało jedynie lewobrzeżne tereny nad rzeką Trebišnica, choć wy dy zaido jektowanew rok 1911 rozserzeri

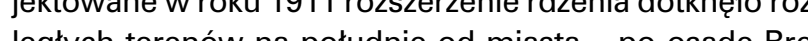

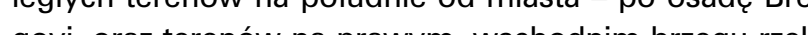
Trebišnicy - osadę Poljce

\section{Woda}

Ze względu na warunki klimatyczne i obfite opady, obszar gminy Trebinje jest najbogatszym w odnawialne za soby naturalne wody - na Bałkanach i w całej Europie. Obszar zlewiska Trebišnjicy obejmuje blisko 4,5 tys. $\mathrm{km}^{2}$ Woda stanowi główny zasób naturalny tego obszaru, jes wykorzystywana do zaopatrywania ludności na cele bytowe, do wytwarzania energii elektrycznej, do działalności przemysłowej i usługowej, oraz w celu jakościowego nawadniania pól krasowych ${ }^{12} \mathrm{w}$ dolinie rzeki. Dogodne warunki do budowy elektrowni wodnych umożliwity realizację czterech obiektów: „Trebinje 1" $i$ „Trebinje 2", „Dubrovnik-Plat" $\mathrm{i}$ „ „Capljina”. poor municipal infrastructure is a distinct quality of peripheral areas, as is the tion of streets and a small number of public spaces. Farmland on separate lots in the middle of typically urban developments is also a common sight.

\section{The fortress}

Bosnia and Herzegovina, inhabited by a Slavic population, was the northernmost province of the Ottothe decisions of the Berlin Congress (1878), which introduced a new division of the world after the Russo-Turkish war the provin came under the occupation of Austria-Hungary. Trebinje, located near the Dubrovnik-Sarajevo road, was the only frontier centre to which a railroad line had been provided Because of this, it was planned to fulfil the function of an essential military transhipment point as well as a logistics depot (Depotpunkt in German). The city also sported a favourable location for the build-up of military forces operating in the direction of Montenegro (ca. $14 \mathrm{~km}$ away from the border at the time). The fundamental task of the Trebinje fortress, in the event of an expected conflict, was the securing of the mobilisation of military forces in the strength of a mountain brigade in the event of a state of emergency? In order for the abovementioned tasks to be performed freely, an expansive enclosed area of a socalled core was required - an internal fortified are resided in barracks buildings - of note is the fact that the defensive barracks complex - Defension slager - ccupied close to a third of the built-up anof the city at the start of the twentieth century. From the south, the former Emperor's Street (orig. Kaiser straße) - currently the main Kralja Petra Prvog Oslobodica Street, runs directly near the former barracks complex $x^{8}$. Along this street, greenery with its orignal, preserved old tree stand, forms a small park ${ }^{9}$. The original layout from the 1880's only included the left-bank areas near the Trebišnjica River, although the development restriction zone in the outer field of the fortifications was also located on the right bank of the river ${ }^{10}$. The expansion of the core, designe in 1911, affected the expansive areas to the south of the city- up to the setlement of Bregovi, or areas o the right, eastern bank of the Trebišnjica-the Poljice .

\section{Water}

ue to climate conditions and heavy rains, the area of the community of Trebinje is the wealthiest site in the Balkans and the entirety of Europe in genera. The area of the conglomeration of the Trebišniica covers close to 4,5 thousand $\mathrm{km}^{2}$. Water constitutes the main natural resource of the area and is used by the population for household purposes, to generate electric power, for industrial and services-related purposes, as well as to qualitatively irrigate karst fields in the river valley'2. Comfortable conditions for the construction of hydroelectric power plants made
Elementy środowiska wodnego wykorzystywane były od początku procesów osadniczych w zalożeniach obronnych Trebinja. Na przełomie XVII i XVIII wieku Turcy zbudowali zamek (Kaste/) stanowiący zarazem ośrodek rozwoju Starego Miasta ${ }^{13}$. Mokra, zasilana wodam rzeki, fosa wokół murów Starego Miasta liczyła ok. 450 m długości i 6 m szerokości. Obecnie zachowany jest jedynie krótki, południowy fragment fosy bezpośrednio Jeczacy sie z rzeka Pozostały ślad fosy wzdtuz zachowalaczący się z rzeka Poź tejeva, Maksimovića Ć kontýn.

Ja poczatku XX wieku, dla celów obronnych wykorzyNa poczlku XX wik Covich celow ob onnych wykorzystano poldery zalow ze znajdujace sie na zachód od

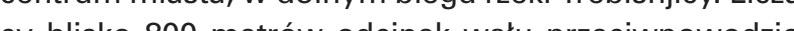
cy busko 800 metrow odcin

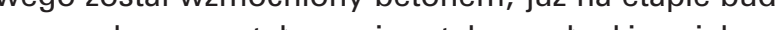
wy osadzon zostaly w nim stalowe slupki zasiekowe stanowiące dodatkowa przeszodę. Koncowy odcinek wału zamykał zbudowany ok. 1912 roku schron Bregovi

Współcześnie, w dolnym biegu rzeki, w sąsiedztwie dawnej osady Bregovi, powstał ogólnodostępny zalew rekreacyjny Bazen Bregovi. Znajdujące się w zasięgu dogodnego dojścia pieszego od centrum miasta, otwart kapielisko, w pelni wykorzystuje potencjal rekreacyjny wody. Pozostałosci historycznych fortyfikacji (wspomniany wyżej schron) dodają tej lokalizacji dodatkowy walor - widoczny ślad tradycji miejsca i burzliwej historii miasta.

\section{Zieleń}

Na obszarze gminy Trebinje występują dwa główne rodzaje klimatu: śródziemnomorski i górski. Klima charakteryzuje się bardzo długim, gorącym i suchym latem oraz łagodnymi, krótkimi i deszczowymi zimami. Średnia roczna temperatura powietrza wynosi około $14,5^{\circ} \mathrm{C}$ a średnie roczne opady wynosza od $1600 \mathrm{do}$ $2800 \mathrm{~mm}$. W ciagu hych (260 dni sto recnych) i tagodna zima, $z$ duza upacią opadów. Górski klimat na tym obszarze jest odmiana klimatu śródziemnomorskiego $z$ łagodnymi wariantam umiarkowanego klimatu kontynentalnego (o nieco chłodniejszych zimach i lecie), obejmuje w większośc tereny położone powyżej $400 \mathrm{~m}$ n.p.m.

Dzieki silnemu wpływowi przede wszystkim klimat śródziemnomorskiego, a także różnorodności typów rzeźby terenu i gleb na obszarze Trebinje, rozwinęły sie specyficzne zbiorowiska roślinne dla strefy nadmorskiej ale także dla obszaru przybrzeżnego (m.in. stanowisk dębu ostrolistnego (Quercus ilex)). Ta niezwykle ważn różnorodność biologiczna wymaga specjalnych środków ochronnych - ochrona obszarowa lasów dębowych Restala w planie zagospodarowania przestrzennego Republiki Serbskiej. Obszar Trebinje znajduje sie rownież w strefie ekspansji grabu (Carpinteum orientalis adriaticum), ciepłolubnych dębow szypułkowych (Quercetalia pubescentis), oraz wiązu czarnego i białego (Ostryo - Carpinetum orientalis). Dębowe lasy leegowe possible to build four structures: „Trebinje $1^{\prime \prime}$ and "Trebinje 2", „Dubrovnik-Plat” and "Čapljin “"

Elements of the aquatic environment have been used since the beginning of settlement processes in Trebinja's defensive layouts. At the turn of the seventeenth and eighteenth centuries the Turks built a casthe (Kaste/) which also constituted a centre of the de velopment of the Old Town'13. The wet moat around the walls of the Old Town, fuelled by the waters of present, only a short, southern fragm $6 \mathrm{~m}$ wide. At hes been preserved, directly conneting to the river. The remaining trace of the moat along the surviving defensive walls continues the outline of Dositejeva, Maksimovića and Ćorovića streets.

At the beginning of the twentieth century, the flood polders located to the west of the city, in the lower course of the Trebišnjica river, were used for defensive purposes. The nearly 800-metres-long embankment section was reinforced with concrete; steel abattis were placed in it already during the construction stage, constituting an additional obstacle. The final section of the embankment was enclosed by the Bregovi shelter built around 1912, which was armed with machine gun emplacements.

At present, in the lower course of the river, in the vicinity of the former settlement of Bregovi, a freely accessible artificial recreational lake was built, calle Bazen Bregovi. The open bathing spot, located at from the jity centre, fully utilises the recreation tential of water. The remains of historical fortifications (the previously mentioned shelter) add additional valwe to this location-a visible trace of the tradition of the place and of the turbulent history of the city.

\section{Greenery}

There are two main types of climate in the territory of the community of Trebinje: Mediterranean and mountain climate. The climate is characterised by a very long, hot and dry summer and mild, short and rainy whters. The average yearly air temperature is around 1600 to $2800 \mathrm{~mm}$. There are many hot days throughout the year ( 260 sunny days) and a mild winter with out the year (260 sunny days) and a mild winter with area is a variant of the Mediterranean climate with mild variants of a temperate continental climate (with slightly cooler winters and summers), mostly covering areas located above $400 \mathrm{~m}$ above sea level.

anks to strong influence of, primarily, the Mediternean climate, as well as the variety of the types of rrain and soils in the Trebinje area, plant groupings distinct of seaside zones have developed, as well as those distinct of coastal zones (e.g. holm oak (Quercus ilex) stands). This extraordinarily important biological diversity requires special protective measures-area-based protection of oak forests has been introduced into the spatial development plan of the ated in the zone of the expansion of the hornbea tree (Carpinteum orientalis adriaticum), thermophilic 
zabudowy, rozwijało się w myśl zasad określonych obecnie mianem rozwoju zrównoważonego. Specyficzna lokalizacja i dostępne zasoby naturalne zostały efektywnie wykorzystane przez organizm miejski, tak jak i zachowane elementy struktury pofortyfikacyjnej. Kameralna skala miasta powoduje, że większość funkcji użyteczności publicznej znajduje się w zasięgu dojścia pieszego ${ }^{18}$. Tak zwana „błekitno-zielona infrastruktura" stanowi zaś istotny element kompozycji, czytelnie wiążąc sekwencję przestrzeni publicznych w ścisłym centrum.

\section{PRZYPISY}

1 Szerzej za: Karan I., 2014, Trebinje on the Border between East and West. Heritage and Memory of Bosnian-Herzegovinian Town, w: Bitacora 24 (2), Universidad Nacional de Colombia, Bogotà.

2 Zabudowa jednorodzinna stanowi 59\% ogółu zabudowy mieszkaniowej w Trebinje. Za: Sustainable Energy Action Plan of Trebinje Municipality, Trebinje 2011.

${ }^{3}$ Karan I., 2014, op. cit.

${ }^{4}$ Zа: Урбанистички План Требиња (2002. - 2015.год.)

${ }_{5}^{5}$ Por. Figurič A., 1930, Trebinje nekada i danas, Ljubljana; Cvijić S., Guzijan J.. 2016. Urban Regeneration as an Instrument of Identity Preservation: a Case Study of Trebinje's Krš District, w: Archives for Technical Sciences, Year VIII, №14, Tehnički Institut, Bijeljina.

${ }^{6}$ Linia kolejowa i dworzec kolejowy zostały oddane do użytku w 1901 roku; zob. m.in. okolicznościowa pocztówka "Bahneröffnungs-Feierlichkeit in Trebinje". W chwili obecnej Trebinje nie posiada połączenia kolejowego - linia kolejowa wraz z infrastrukturą została zlikwidowana w 1976 roku. Otwarcie połączenia i oddanie budynku dworca nastąpiło w 1901 roku.

7 Opis wg Potiorek O., Ausgestaltung der Festung Trebinje, Sarajewo 1911

${ }^{8}$ Niestety, ze względu na katastrofalny stan techniczny cześci historycznych budynków, oraz miejskie plany inwestycyjne, od 2018 rozpoczęto sukcesywne wyburzenia pod nową zabudowę wielorodzinną. ${ }^{9}$ Pas zieleni wysokiej i kwatery niskiej zieleni towarzyszącej budynkom, o powierzchni około 23 arów.

10 Opis wg szczegółowego planu miasta w skali 1:5000, z naniesionym obszarem zakazu zabudowy: Situations-plan von Trebinje, Trebinje 1898.

11 Za: Potiorek O., op. cit., plan w skali 1:10 000

12 Oryg. srb. Poljes.

${ }^{13}$ Figurič A., op. cit., s. 49-50

14 Por. m.in.: Rymsza-Mazur W., Specyfika zieleni zapleczy militarnych Austro-Wegier na wybranych przykładach miast i twierdz, Kraków 2017

${ }^{15}$ Za budowę i utrzymanie fortyfikacji odpowiadała c. k. Dyrekcja Inżynierii.

${ }_{16}$ Drača - dwukolczak śródziemnomorski (Paliurus spina-christi) - kolczasty krzew z kolcami długości ok. $1 \mathrm{~cm}$, rodzimy gatunek w Dalmacji (Chorwacja) i na płaskowyżu Krivošije (Czarnogóra).

17 Za: Plan von Trebinje Stadtrohrnetz, Sarajewo, 1899, plan w skal $1: 3125$.

${ }^{18} \mathrm{M}$. in. z tego względu, jak również z powodu górskiej konfiguracji terenu przedmieść, W Trebinje nie funkcjonuje system transportu publicznego.

\section{LITERATURA}

[1] Cvijić S., Guzijan J., 2016, Urban Regeneration as an Instrument of Identity Preservation: a Case Study of Trebinje's Krš District, w: Archives for Technical Sciences, Year VIII, No14, Tehnički Institut, Bijeljina [2] Figurič A., 1930, Trebinje nekada i danas, Ljubljana.

[3] Karan I., 2014, Trebinje on the Border between East and West. Heritage and Memory of Bosnian-Herzegovinian Town, w: Bitacora 24 (2) Universidad Nacional de Colombia, Bogotà.

[4] Potiorek O., 1911, Ausgestaltung der Festung Trebinje, Sarajewo.

[5] Rolf R., 2011, Festungsbauten der Monarchie. Die k.k.-und k.u.k. Befestigungen von Napoleon bis Petit Trianon, eine typologische Studie, Middelburg.

[6] Rymsza-Mazur W., 2017, Specyfika zieleni zapleczy militarnych Austro-Wegier na wybranych przykładach miast i twierdz, praca doktorska pod kierunkiem prof. Z. Myczkowskiego, WA PK, Kraków.

[7] Sustainable Energy Action Plan of Trebinje Municipality, Trebinje 2011

[8] Urbanistički Plan Trebinja (2002-2015).

[9] Węcławowicz-Gyurkovich E., 2010, Woda w mieście jako przestrzeń publiczna, w: Czasopismo Techniczne PK z. 6 3-A/2010, s.281-284. the expansion of development, has developed in accordance with the principles that are currently termed as sustainable development. The specific location and accessible natural resources have been effectively utilised by the urban organism, similarly to the surviving elements of the structure of the former fortifications. The cameral scale of the city causes most of its public functions to be located within walking distance ${ }^{18}$. The socalled "blue and green infrastructure" constitutes an essential element of its composition, legibly tying together the sequence of public spaces in the strict city centre.

\section{ENDNOTES}

${ }^{1}$ More from: Karan I., 2014, Trebinje on the Border between East and West. Heritage and Memory of Bosnian-Herzegovinian Town, in: Bitacora 24 (2), Universidad Nacional de Colombia, Bogotà.

2 Single-family buildings constitute $59 \%$ of the overall residential buildings of Trebinje. From: Sustainable Energy Action Plan of Trebinje Municipality, Trebinje 2011

${ }^{3}$ Karan I., 2014, op. cit.

${ }^{4}$ From: Урбанистички План Требиња (2002. - 2015. год.)

${ }^{5}$ Cf. Figurič A., 1930, Trebinje nekada i danas, Ljubljana; Cvijić S., Guzijan J., 2016, Urban Regeneration as an Instrument of Identity Preservation: a Case Study of Trebinje's Krš District, in: Archives for Technical Sciences, Year VIII, No14, Tehnički Institut, Bijeljina.

${ }^{6}$ The railway line and train station were opened for use in 1901; see the memorial postcard entitled "Bahneröffnungs-Feierlichkeit in Trebinje". At present Trebinje does not possess a railway connection-the railway line and its infrastructure were dismantled in 1976. The opening of the railway line and the train station building took place in 1901.

7 Description according to Potiorek O., Ausgestaltung der Festung Trebinje, Sarajevo 1911

8 Unfortunately, due to the catastrophic technical condition of some historical buildings, as well as the city's development plans, successive demolitions meant to make room for new multi-family developments have been taking place since 2018.

${ }^{9} \mathrm{~A}$ belt of tall greenery and beds of low-lying greenery accompanying buildings, with an area of around 23 ares.

${ }_{10}$ Description according to a detailed plan of the city drawn to a scale of 1:5000, with a marked area of development restriction: Situations-plan von Trebinje, Trebinje 1898.

${ }^{11}$ After: Potiorek O., op. cit., plan drawn to a scale of 1:10 000.

12 Orig. Poljes in Serbian.

${ }^{13}$ Figurič A., op. cit., p. 49-50.

14 Cf. among others.: Rymsza-Mazur W., Specyfika zieleni zapleczy militarnych Austro-Wegier na wybranych przykładach miast i twierdz, Kraków 2017.

15 The construction and maintenance of fortifications was the responsibity of the imperial-royal Engineering Directorate.

${ }_{16}$ Drača - garland thorn (Paliurus spina-christi)—a thorny bush with centimetre-long thorns, a species native of Dalmatia (Croatia) and the Krivošije Plateau (Montenegro).

17 After: Plan von Trebinje Stadtrohrnetz, Sarajevo, 1899, plan drawn to a scale of 1:3125.

18 It was for this reason, among others, as well as due to the mountainous configuration of the terrain of the suburbs, that Trebinje does not have a functioning public transport system.

\section{BIBLIOGRAPHY}

[1] Cvijić S., Guzijan J., 2016, Urban Regeneration as an Instrument of Identity Preservation: a Case Study of Trebinje's Krš District, w: Archives for Technical Sciences, Year VIII, No14, Tehnički Institut, Bijeljina. [2] Figurič A., 1930, Trebinje nekada i danas, Ljubljana.

[3] Karan I., 2014, Trebinje on the Border between East and West. Heritage and Memory of Bosnian-Herzegovinian Town, in: Bitacora 24 (2), Universidad Nacional de Colombia, Bogotà.

[4] Potiorek O., 1911, Ausgestaltung der Festung Trebinje, Sarajewo.

[5] Rolf R., 2011, Festungsbauten der Monarchie. Die K.K.- und K.u.k. Befestigungen von Napoleon bis Petit Trianon, eine typologische Studie, Middelburg.

[6] Rymsza-Mazur W., 2017, Specyfika zieleni zapleczy militarnych Austro-Wegier na wybranych przykładach miast i twierdz, doctoral dissertation under the supervision of prof. Z. Myczkowski, WA PK, Kraków. [7] Sustainable Energy Action Plan of Trebinje Municipality, Trebinje 2011.

[8] Urbanistički Plan Trebinja (2002-2015).

[9] Węcławowicz-Gyurkovich E., 2010, Woda w mieście jako przestrzeń publiczna, in: Czasopismo Techniczne PK b. 6 3-A/2010, p.281-284. 